\title{
ASSOCIATION BETWEEN HOTEL HUMAN RESOURCE MANAGEMENT PRACTICES AND ORGANIZATIONAL CULTURE
}

\author{
Syed Munir Barakbah Syed Faozi Barakbah, Azrin Abdul Razak, \\ May May Grace Derioh \\ UNITAR International University, Malaysia \\ Fakhrulzaman Abdullah \\ Suliman Al-Rajhi Colleges, UAE
}

\begin{abstract}
The purpose of this study was to understand the nature of human resource management (HRM) practices and study the concept of organizational culture in the midscale and upscale hotel organizations. Thus, the main theme of this study was an executive-level position in the HRM department/division of the hotel which included detailed examination on (1) the five different types of HRM practices such as $H R$ planning, staffing, training and development, appraisal, and compensation; and (2) the three elements of organizational culture such as employee relations, creativity/risk-taking, and efficiency/pride emphasis. The next part determines the extent of association between the HRM practices and the organization's culture orientation. The number of hotel organisations included in the study was 50 hotels selected midscale and upscale hotels in the Klang Valley. The findings from this research indicate that overall HRM practices were found to be mixed with some inclination towards meeting current requirements whilst some were more geared towards future requirements. The organisation's culture orientation was relatively open and in support of employee-management relationships, some organizational support for employees' creativity and risk-taking activities, and employees' pride with their organizations.
\end{abstract}

Key words: HRM practices, organizational culture, HR planning, staffing, training and development, appraisal, compensation, employee relations, creativity/risk-taking, efficiency/pride emphasis.

Cite this Article: Syed Munir Barakbah Syed Faozi Barakbah, Azrin Abdul Razak, May May Grace Derioh and Fakhrulzaman Abdullah, Association between Hotel Human Resource Management Practices and Organizational Culture, International Journal of Management, 11(12), 2020, pp 354-367.

http://iaeme.com/Home/issue/IJM?Volume $=11 \&$ Issue $=12$ 


\section{INTRODUCTION}

In today's dynamic market, the high role of human resource management (HRM) has been increased. It is the organization's challenge to deal with the internal resources to cope with government policy change. The companies emphasize successful HRM practices as a designed strategy to create a transparent, versatile, and caring style of management (David, 2007).

One of the main objectives of HRM is to increase organisation's performance (Paauwe, Guest \& Wright, 2010). Pfeffer (1998) stressed the importance of gaining competitive advantage through employees and noted the importance of multiple human resource practices needed to gain this benefit. Changing labor market conditions and new business thinking require HRM strategies which include hiring and retaining the right people and providing ethical and cultural leadership (SHRM, 2015). One of the biggest challenges today for HR personnel is to develop employees in line with global environmental factors as well as the international marketplace (Andersen, Cooper \& Zhu, 2007). HR is not only limited to promote the operation of the company but committed to take a lead in building strategic and competitive edge by being involved in making strategic decisions (Golden \& Ramanujam, 1985). Walker (1994) reveals on HR incorporation with companies requires a brand-new paradigm for managing people in an organization, as well as propose solutions for many complicated issues related to organizational success.

Fombrun (1983) noted that hard HRM practices focus on the procedural aspects of the HRM functions. The generic functions performed by the HRM divisions of any firm are HR planning, staffing, training and development, appraisal and evaluation, and compensation. Storey (1987) had distinguished between hard and soft forms of HRM. He stated that "hard" HRM focused on the resource side of human resources. It emphasized costs in the form of headcounts and places control firmly in the hands of management. Their role is to manage numbers effectively, keeping the workforce closely matched with requirements in terms of both bodies and behaviour (Storey, 1998).

Bach (2005) viewed the nature of "hard" HRM as follows: (1) HRM is unitarist (employer and employee interests should coincide) with the emphasis on organizational effectiveness, (2) interests of other stakeholders such as employees are marginalized, (3) there is a predominant interest on the individual firm - specifically, within the firm where the focused was on individual employee motivation and aspiration, (4) there is a consequent playing down of external and collective (unionization) issues. Legge (1995) observed that the hard HRM approach had some kinship with scientific management as people are reduced to passive objects that are not cherished as a whole person, but assessed on whether they possess the skills/attributes the organization requires. The 'hard' model was mainly considered as a factor of production, or a variable cost of doing business, whose supply should co-vary with the product market demand (Fombrun, Tichy \& Devanna, 1984; Hendry \& Pettigrew, 1986).

The purposes of the study were to: (1) understand the nature of HRM practices in the midscale and upscale hotel organizations, (2) study the concept of organizational culture in the midscale and upscale hotel organizations, and (3) determine the extent of association between the HRM practices and the organizational culture orientation. It is proposed that there would be a close association between the HRM practices and the organizational culture orientation. 


\section{Study Framework}

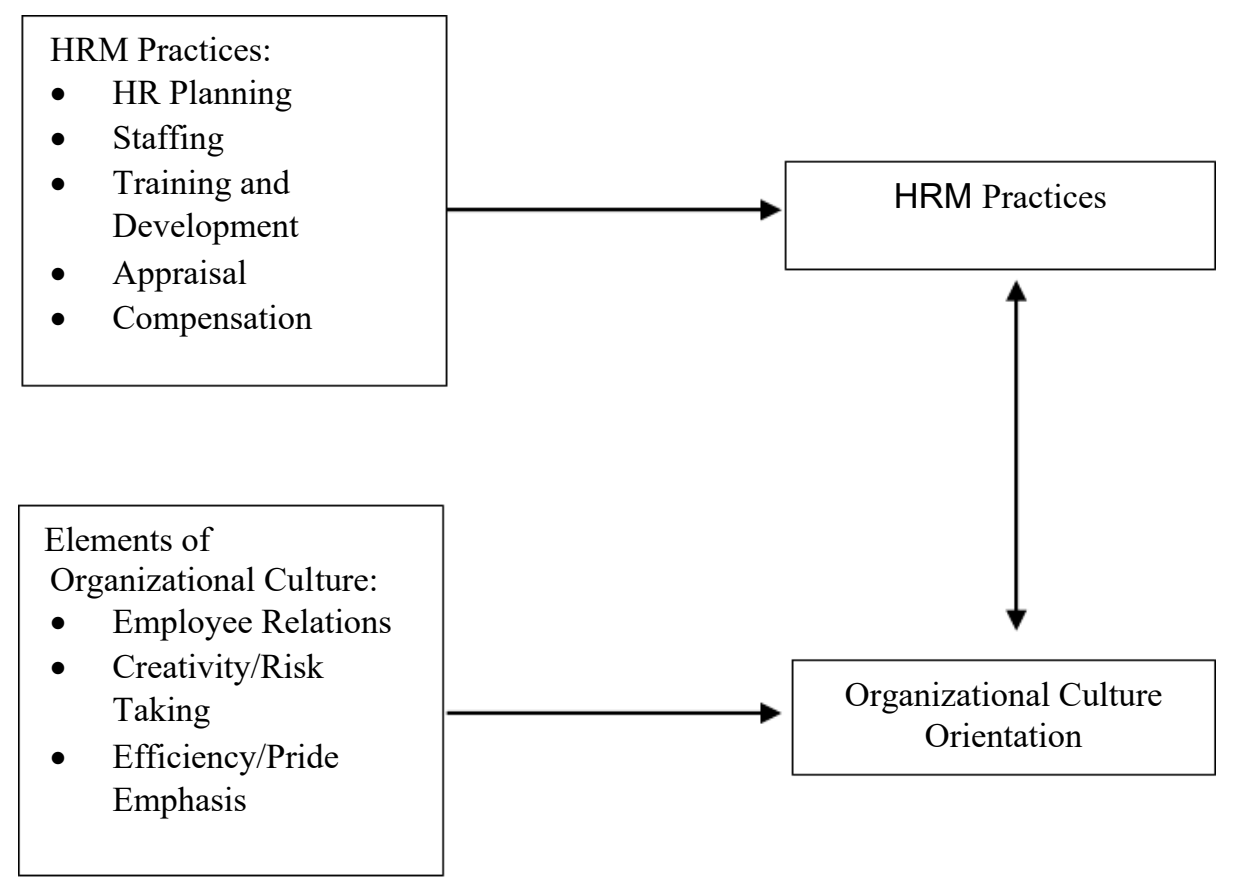

\section{OVERVIEW ON LITERATURE}

The hard or functional aspects of HRM comprised the functions of (1) HR planning which is the process of systematically reviewing human resource requirements to ensure that the required number of employees, with the required skills, is available when and where they are needed (Armstrong, 2001); (2) Staffing which is defined as the process that ensures the organization always has the appropriate number of employees with the relevant skills in the right jobs at the right time to achieve the organization's objectives (Rynes, Brown \& Colbert, 2002). Staffing function is seen as comprising of two separate functions which are (i) Recruitment activities which include searching for and obtaining potential job candidates in sufficient numbers and quality so that the organisation can select the most appropriate people to fill its job needs (Dowling \& Schuler, 1990), and (ii) Selection activities which involved predicting which candidates will make the most appropriate contribution for now and in the future (Hackett, 1991); (3) Training and development: Training is defined as the systematic process of altering behaviour permanently and the objective is to meet specific purposes. It represented a complex process which includes a mixture of activities intended to improve the performance of individual or groups within the organization (Holton \& Baldwin, 2000). The development function, in contrast to the training function, is associated with building employee competence and is designed to ensure that each employee is properly equipped with the knowledge, skills and proper attitude to do the job. Also, it ensures that the organization has a continuous supply of human resource talents (Pool \& Pool, 2007); (4) Appraisal is the systematic description of the job-relevant strengths and weaknesses of an individual or group. It includes performance management which is the total process of observing an employee's performance with job requirements over some time and then making an evaluation of it (Grund \& Przemeck, 2012); and (5) Compensation function relates to activities to ensure that employees received the appropriate reward in return for their services to the organization. Therefore, it may include direct cash payments, indirect payments (employee benefits) and incentives (Fein, 2001). 
Deshpande and Webster (1989) observed organizational culture as a pattern of shared values and beliefs that help individuals understand organizational functioning. They added that it provides the organization with the norms for behaviour. Organizational culture was conceptualized and quantified in terms of widely shared and strongly held values by Chatman and Jehn (1994). Rousseau (1990) further indicated that elements of organizational culture ranged from fundamental assumptions through values and behavioural norms to actual patterns of behaviour. O'Reilly, Chatman, and Caldwell (1991) identified the following dimensions of organizational culture using an instrument they developed which is called the Organizational Culture Profile (OCP). The dimensions measured were innovation, stability, respect for people, outcome orientation, team orientation, and aggressiveness. Olsen, Tse, and West (1998) further added that the culture of an organization "makes members behave and act in a certain way'. They suggested that culture is a defined set of values and norms that are well understood and accepted by the majority of employees in an organization.

\section{RESEARCH METHODOLOGY}

The study uses the case study design since the objectives are to understand the hotel organizations' practices that relate specifically to human resource management practices and the orientations of the organizational structure, processes, and culture. The variables are examined in a limited number of hotels. The study uses the cross-sectional design where the data collection extended over only a 3 - week period.

Primary data are collected via mail survey with selected hotel organizations. Secondary information is derived from research reports (thesis, and journal articles) and published data by Tourism Malaysia, Ministry of Tourism, and Economic Reports.

The study examined selected midscale and upscale hotels in the Klang Valley. It is a convenience sample, selected from the list of hotels in the area as published in the directory of hotels by Tourism Malaysia. Fifty hotels were solicited for participation in the study. The respondents represent those holding at least an executive-level position in the human resource management department/division of the hotel.

Two (2) instruments are required for the study. These two instruments consisted of structured questions aimed at identifying: HRM practices and organizational culture. Questions on the respondents' profiles are included to ensure the reliability of responses. The two instruments are compiled in the form of a questionnaire that are mailed out to the hotels.

\subsection{Hard HRM Practices: 5 Dimensions}

\section{A. Human Resource Planning (5)}

1. Human resource planning is formalized and systematic

2. Human resource requirements consider the business development of the organization

3. Career ladders are well established in the organization.

4. Only the Human Resource department plans the Human resource requirements

5. The quantity and quality of employees required is planned more than 1 year ahead of requirement.

\section{B. Staffing (5)}

1. Criteria for promotion are known to all employees

2. Promotional opportunities are limited

3. Management discusses employees' career development

4. Employees can self-nominate for promotion 
5. The organization emphasizes on external hiring only.

C. Training and Development (6)

1. Training programs are designed around current job requirements

2. Training programs are developed based on responding to current needs

3. Training programs are initiated by the HRM department or top management

4. Training programs emphasize on productivity needs of the organization

5. The organization welcome volunteers to participate in training programs

6. Training programs include general and broad-based knowledge

D. Appraisals (8)

1. Employees feel that their wages commensurate with their performance

2. Employees are allowed to self-evaluate their performance

3. The evaluation process is informal

4. Evaluation is an on-going process

5. Employees are evaluated as individuals

6. Management always insists on performance improvement

7. Employees are given feedback regularly on their performance

8. Employee evaluation is used for rewards and remedial

E. Compensation (5)

1. The organization has a standard and fixed compensation package

2. Employees feel that they have a secure job with the organization

3. Compensation is a routine adjustment in wages according to seniority

4. Based salary is determined by market rates for similar jobs

5. Long-term impact of compensation is considered

\subsection{Organizational Culture:3 Dimensions}

\section{A. Employee Relations (4)}

1. The employees trust the management

2. Employees have independence on how to do their job.

3. The organization encourages closeness among the employees at all levels.

4. Employees feel that the work that they do is meaningful to them

B. Creativity and Risk-Taking (5)

1. Management encourages creativity amongst its employees

2. Employees are very innovative and enterprising

3. Employees feel that they can do their job

4. The organization believes in taking risks

5. Management is cautious in trying new ideas

C. Efficiency/Pride Emphasis (4)

1. The organization focuses on efficiency improvement. 
Syed Munir Barakbah Syed Faozi Barakbah, Azrin Abdul Razak, May May Grace Derioh and Fakhrulzaman Abdullah

2. The organization is solid and established in the industry

3. Employees feel safe in the organization

4. Employees are proud to be working for the organization

Scale: A self-rating instrument with 4-point Likert scale ranging is used to tap the extent that each practice is applied in the hotels.

Table 1

\begin{tabular}{|c|c|c|c|}
\hline $1.00-1.74$ & $1.75-2.49$ & $2.50-3.24$ & $3.25-4.00$ \\
\hline Low & Somewhat Low & Somewhat High & High \\
\hline
\end{tabular}

\section{STUDY FINDINGS}

\subsection{Organization and Respondent Profile}

An analysis of the profile of respondents indicated that, from the 21 hotels respondents, $67 \%$ of the respondents held positions as either personnel executive or training manager, $19 \%$ were human resource managers, while $14 \%$ were Human resource supervisors. The hotels, on average had 395 rooms, with 190 full-time employees and of which, 63 employees or 33\% were frontline.

\subsection{HRM Practices}

Hard HRM practices focused on the procedural aspects of the HRM functions. The generic functions that are performed by the HRM divisions of any firm are the HR planning, staffing, training and development, appraisal and evaluation, and compensation. The HRM practices or the "hard" HRM practices orientation were measured on those 5 functional area dimensions.

\subsection{HR Planning Function}

HR planning is the process for identifying an organisation's current and future human resource requirements, for developing and implementing plans to meet these requirements and for monitoring their overall effectiveness. HR planning was measured based on 5 items which are the (1) formalization of HR planning, (2) consideration of business development, (3) establishment of career ladders, (4) planning of HR requirements, and (5) duration of planning. As illustrated in Table 1, the overall mean score for HR planning was 2.24.

Table 2 HR Planning

\begin{tabular}{|c|l|c|l|}
\hline No. & \multicolumn{1}{|c|}{ Dimensions } & Mean Score & \multicolumn{1}{c|}{ Meaning } \\
\hline 1 & Planning is formalized & 1.81 & Quite formalized \\
\hline 2 & $\begin{array}{l}\text { Planning considers business } \\
\text { development }\end{array}$ & 1.76 & $\begin{array}{l}\text { Did not quite consider the } \\
\text { business development }\end{array}$ \\
\hline 3 & Establish career ladders & 1.91 & Not clearly established \\
\hline 4 & $\begin{array}{l}\text { HR department plans HR } \\
\text { requirements }\end{array}$ & 3.05 & HR played a major role \\
\hline 5 & $\begin{array}{l}\text { Planning duration over 1-year } \\
\text { period }\end{array}$ & 2.67 & $\begin{array}{l}\text { Somewhat mixed - oriented } \\
\text { towards formal and short term }\end{array}$ \\
\hline & Overall Mean & 2.24 & $\begin{array}{l}\text { Some inclination towards } \\
\text { reactive. }\end{array}$ \\
\hline
\end{tabular}

This indicated that there were some mixtures in the orientation as can be observed from the mean scores for the individual items. A score that is closer to 1 would indicate an inclination towards some degree of conservatism or reactivity in the approach in HR planning. 
It appeared that planning was quite formalized as indicated by the mean score of 1.81 . Planning did not quite consider the business development of the organization judging from the mean score of 1.76, and career ladders were not clearly established as indicated by the mean score of 1.91. The respondents indicated that the HR department had a major part in determining the HR requirements of the organization and there were mixed opinions on the planning horizon.

\subsection{Staffing Function}

The staffing function is defined as the process that ensures the organization always has the appropriate number of employees, with the relevant skills, in the right jobs, at the right time, to achieve organizational objectives. The staffing function includes both the activities related to recruitment and selection of potential employees, whether through internal or external sources. The activities involved (1) attracting qualified people to the organization, (2) selection process, (3) orientation and induction programs, (4) employee transfer, (5) process of promotion or demotion, employee separation, and resignation or discharge. The staffing function was rated as average with a mean score of 2.52, as shown in Table 3.

Table 3 Staffing Function

\begin{tabular}{|c|l|c|l|}
\hline No. & \multicolumn{1}{|c|}{ Dimensions } & Mean Score & \multicolumn{1}{c|}{ Meaning } \\
\hline 1 & Explicit Promotional criteria & 3.24 & Quite explicit - transparent \\
\hline 2 & Promotional opportunities & 1.71 & Somewhat limited \\
\hline 3 & $\begin{array}{l}\text { Career development - participation } \\
\text { by Management }\end{array}$ & 3.24 & $\begin{array}{l}\text { High level of management } \\
\text { participation }\end{array}$ \\
\hline 4 & Self-nomination for promotion & 2.38 & Somewhat allowed \\
\hline 5 & Emphasize external hiring & 2.05 & Quite low emphasis \\
\hline & Overall Mean & 2.52 & $\begin{array}{l}\text { Mixed - More fixed and limited } \\
\text { with a slight orientation towards } \\
\text { employees }\end{array}$ \\
\hline
\end{tabular}

This indicated that there might be some differences in orientations on the 5 items. The respondents felt that the promotional criteria were somewhat transparent as indicated by the mean score of 3.24. However, they also indicated that the opportunities for promotion were quite limited (mean score of 1.71) even though management did discuss career development with the employees as evidence by the relatively high score of 3.24. Respondents generally felt that employees can nominate themselves for promotion (mean score of 2.38), and the organizations did not place a strong emphasis on external hiring as indicated by the mean score of 2.05 .

\subsection{Training and Development Function}

The training function includes activities to ensure that employees with the knowledge, skills, and appropriate behavioural dispositions needed are available for their present jobs. The development function, on the other hand, includes activities that are designed to improve employee competency and organizational performance. Thus, it represented a continuous effort of upgrading and improving employees' capabilities. As illustrated in Table 3, the mean score for the training and development function was 2.16 which indicated, to some extent, the inclination towards conservativeness in this functional approach. 5 items were used to measure this variable. The first item was the design of the job requirement, which was rated at 2.05. This indicated that the training and development programs were offered mainly to address current job requirements. The next item also relates to the inclination of the training and development programs. The mean score was much lower which indicated that the programs were developed based also on responding to current needs. These training and 
development programs were mainly initiated by the top management or the HR department, rather than the individual departments. The emphasis of the programs was on the productivity needs of the organizations (mean score of 1.67). Some programs invited volunteers for participation while others were designed for specific employee groups, as reflected by the mean score of 2.67. The programs were quite specifics that were targeted to meet certain goals as indicated by the mean score of 3.29.

Table 4 Training and Development Function

\begin{tabular}{|c|l|c|l|}
\hline No. & \multicolumn{1}{|c|}{ Dimensions } & Mean Score & \multicolumn{1}{c|}{ Meaning } \\
\hline 1 & Designed on job requirement & 2.05 & $\begin{array}{l}\text { Focus on the current job } \\
\text { requirement }\end{array}$ \\
\hline 2 & Based on current needs & 1.57 & Focus on current needs only \\
\hline 3 & Determination of programs & 1.71 & $\begin{array}{l}\text { Mainly by HR/Top } \\
\text { management }\end{array}$ \\
\hline 4 & Programs emphasis & 1.67 & Mainly on productivity needs \\
\hline 5 & Participation in programs & 2.67 & Somewhat opened \\
\hline 6 & Knowledge-based objectives & 3.29 & Very specific target \\
\hline & Overall Mean & 2.16 & $\begin{array}{l}\text { Slight inclination towards } \\
\text { current needs }\end{array}$ \\
\hline
\end{tabular}

\subsection{Appraisal Function}

The Appraisal function involves a systematic review and evaluation of job performance to assess accomplishments and it involves development plans. It is a process that will determine the rewards for the employees' performance. The process should involve discussions on work expectations and review of performance between managers and employees. The appraisal function demands the systematic description of job-relevant strengths and weaknesses of an individual employee or employee group. It includes performance management which is the total process of observing an employee's performance with job requirements over some time and then making an evaluation of it. As indicated in Table 4, the appraisal function was given an overall moderate rating with a mean score of 2.44. 8 items were used to measure the orientation of the appraisal function. The first item was the extent to which the respondents felt that the wages commensurate with performance. Here, the mean score was 2.57 which indicated that they felt that the wages were somewhat in line with performance.

Table 5 Appraisal Function

\begin{tabular}{|c|l|c|l|}
\hline No. & \multicolumn{1}{|c|}{ Dimensions } & Mean Score & \multicolumn{1}{c|}{ Meaning } \\
\hline 1 & $\begin{array}{l}\text { Wages commensurate with } \\
\text { performance }\end{array}$ & 2.57 & Quite commensurate \\
\hline 2 & Opportunity for self-evaluation & 2.95 & Opportunities provided \\
\hline 3 & Evaluation process is informal & 2.38 & Mixture \\
\hline 4 & Evaluation process is on-going & 3.29 & Continuous process \\
\hline 5 & Evaluated as individuals & 1.62 & $\begin{array}{l}\text { Mainly evaluated } \\
\text { individually }\end{array}$ \\
\hline 6 & $\begin{array}{l}\text { Performance Improvement - } \\
\text { pressure by management }\end{array}$ & 3.05 & Somewhat high level \\
\hline 7 & Employees given feedback & 1.81 & Somewhat low \\
\hline 8 & $\begin{array}{l}\text { Evaluation used for reward and } \\
\text { remedial }\end{array}$ & 1.81 & Mainly for remedial \\
\hline & \multicolumn{2}{|l}{2.44} & $\begin{array}{l}\text { Moderate with some } \\
\text { participation but mainly for } \\
\text { remedial needs }\end{array}$ \\
\hline
\end{tabular}


On the opportunity for self-evaluation, the score was slightly higher which meant that the employees were allowed some opportunity to rate themselves. When asked whether the evaluation process was informal or formal, the responses were mixed. A majority (3.29) of the responses indicated that it was an on-going process. The employees were, however, evaluated mainly as individuals rather than as groups. They also felt that the appraisal was mainly not used for performance improvement, but It was used mainly for reward and remedial purposes as indicated by the mean score of 1.81. Also, employees were often not provided with feedback on their performance.

\subsection{Compensation Function}

The compensation function relates to activities that ensure employees received the appropriate reward in return for their services to the organization. The compensation process represents the flow of events that determined the number of wages, salaries, and incentives that are paid, and the supplementary benefits and non-financial rewards such as awards and recognitions. As shown in Table 5, the compensation function was overall rated as slightly below average, which meant that there was a tendency to be slightly conservative in orientation.

Five items were used to measure this variable. Respondents were asked to indicate whether the compensation package as standard and fixed or flexible. They responded that it was somewhat fixed and standard as evident by the mean score of 1.91. The employees felt that their job was somewhat not secure (mean score of 1.62). The respondents indicated that wages were adjusted according to seniority, but initial wages were determined by market rates. Also, the hotels did consider some long-term impacts of the compensation method that they used.

Table 6 Compensation Function

\begin{tabular}{|c|l|c|l|}
\hline No. & \multicolumn{1}{|c|}{ Dimensions } & Mean Score & \multicolumn{1}{c|}{ Meaning } \\
\hline 1 & $\begin{array}{l}\text { Nature of compensation } \\
\text { package }\end{array}$ & 1.91 & Somewhat standard and fixed \\
\hline 2 & Job security & 1.62 & Somewhat low \\
\hline 3 & Wage adjustment & 2.19 & Mainly based on seniority \\
\hline 4 & Initial wages - market rates & 3.14 & Some extent \\
\hline 5 & $\begin{array}{l}\text { Consideration of the impact of } \\
\text { compensation }\end{array}$ & 3.10 & $\begin{array}{l}\text { Somewhat long-term impact } \\
\text { considered }\end{array}$ \\
\hline & Overall Mean & 2.39 & $\begin{array}{l}\text { Inclination towards both } \\
\text { fixed and current orientation. }\end{array}$ \\
\hline
\end{tabular}

\subsection{Overall Hard HRM Practices}

The hard HRM practices indicated an overall moderate approach, as shown in Table 6 . The HR Planning function was rated at a mean score of 2.24, which indicated that there were some mix orientations as were observed from the mean scores for the individual items. The overall orientation was slightly reactive. The staffing function was rated with a mean score of 2.52 which showed that there were some differences in orientations. The overall mean score indicated a balance between fixed and flexible practices. The mean score for the training and development function was 2.16, which indicated, to some extent, the conservative inclination. It tended to lean on meeting current requirements for skills. The appraisal function was overall rated as moderate with a score of 2.44. It showed a combination of emphasis on the individual employee and employee groups. The compensation function was rated as slightly below average which meant that there was a general tendency towards a slightly conservative orientation. It also tended to be slightly in favour of fixed practices. Thus, the overall hard 
HRM practices, with an average score of 2.35, indicated the slight orientation and preference for individual and fixed approaches.

Table 7 Overall HRM Orientation

\begin{tabular}{|c|l|c|l|}
\hline No. & \multicolumn{1}{|c|}{ Dimensions } & Mean Score & \multicolumn{1}{c|}{ Meaning } \\
\hline 1 & HR Planning & 2.24 & Inclination towards reactive \\
\hline 2 & Staffing & 2.52 & $\begin{array}{l}\text { More fixed and limited with a slight } \\
\text { orientation towards employees }\end{array}$ \\
\hline 3 & $\begin{array}{l}\text { Training and } \\
\text { Development }\end{array}$ & 2.16 & $\begin{array}{l}\text { Slight inclination towards current } \\
\text { needs }\end{array}$ \\
\hline 4 & Appraisal & 2.44 & $\begin{array}{l}\text { Moderate with some employees' } \\
\text { participation but mainly for } \\
\text { remedial needs }\end{array}$ \\
\hline 5 & Compensation & 2.39 & $\begin{array}{l}\text { Inclination towards both fixed and } \\
\text { current orientation }\end{array}$ \\
\hline & Overall Mean & 2.35 & Mixed emphasis \\
\hline
\end{tabular}

\subsection{Organizational Culture}

Organizational culture is defined as a pattern of shared values and beliefs that help individual employee understands organizational function. It also provides them with the norms for behaviour. The organizational culture orientation was tapped based on the combination of mean score derived on 3 variables which were: employee relations, creativity or risk-taking, and emphasis on efficiency or pride.

\subsection{Employee Relations}

Employee relations determined the level of trust or closeness between management and employees. Four items were used to gauge the nature of employee relations. The first item was intended to find out to what extent the employees trust management. It was encouraging to note that employees generally did trust management, as evident from the mean score of 3.66 as is shown in Table 7. To a slightly lesser extent, the organization did encourage closeness. Employees also found their work to be quite meaningful and they did require a somewhat high degree of independence when executing their tasks, as indicated by the mean score of 3.70. Thus, overall the organizations generally did support activities that bring management and employees closer as evident by the mean score of 3.57.

Table 8 Employee Relations Variable

\begin{tabular}{|l|l|c|l|}
\hline No & \multicolumn{1}{|c|}{ Factors } & $\begin{array}{c}\text { Mean } \\
\text { Score }\end{array}$ & \multicolumn{1}{|c|}{ Level } \\
\hline 1 & Employees trust management & 3.66 & Relatively trustful \\
\hline 2 & $\begin{array}{l}\text { Employees have interdependence on } \\
\text { job }\end{array}$ & 3.70 & High level of interdependence \\
\hline 3 & Organization encourages closeness & 3.13 & $\begin{array}{l}\text { Quite a high level of } \\
\text { encouragement }\end{array}$ \\
\hline 4 & Work is meaningful for employees & 3.80 & Very Meaningful \\
\hline & Employee Relations & 3.57 & Very close/tight relationship \\
\hline
\end{tabular}

\subsection{Creativity or Risk-Taking}

The creativity or risk-taking variable was aimed at finding out the organizations' inclination towards allowing employees to think and suggest job-related improvements. 5 items were used to determine this inclination. It was apparent from the mean score of 3.24 as indicated in 
Table 9, that management did encourage creativity among employees and that management did believe in taking risks (3.05). This probably also leads to the employees' innovativeness (3.00). However, management remained slightly cautious in implementing the new ideas as suggested/developed by employees, as shown in the mean score of 2.57 . In contrast, employees still felt apprehensive about their ability to do their jobs. Thus, the overall findings, with an average score of 2.80, indicated that there was some support for creativity and risk-taking activities.

Table 9 Creativity/Risk Taking Variable

\begin{tabular}{|c|l|c|l|}
\hline No & \multicolumn{1}{|c|}{ Factors } & $\begin{array}{c}\text { Mean } \\
\text { Score }\end{array}$ & \multicolumn{1}{|c|}{ Level } \\
\hline 1 & Management encourages creativity & 3.24 & $\begin{array}{l}\text { Relatively high } \\
\text { encouragement }\end{array}$ \\
\hline 2 & Employees are innovative & 3.00 & Quite innovative \\
\hline 3 & Employees feel able to do the job & 2.14 & Moderately felt able \\
\hline 4 & Organization believes in taking risks & 3.05 & $\begin{array}{l}\text { Quite believes in taking } \\
\text { risks }\end{array}$ \\
\hline 5 & $\begin{array}{l}\text { Management cautious in trying new } \\
\text { ideas }\end{array}$ & 2.57 & Moderately cautious \\
\hline & Creativity/Risk Taking & 2.80 & $\begin{array}{l}\text { Moderate level of } \\
\text { creativity/risk-taking }\end{array}$ \\
\hline
\end{tabular}

\subsection{Efficiency and Emphasis on Pride}

The efficiency and pride variable were intended to gauge the organizations' level of emphasis on efficiency and the employees' feeling towards their jobs and the organizations. 4 items were used in measuring this variable. The organization tended to overemphasize on efficiency, as indicated by the mean score of 1.48 in Table 10 .

Table 10 Efficiency/Pride Emphasis Variable

\begin{tabular}{|c|l|c|l|}
\hline No & \multicolumn{1}{|c|}{ Factors } & $\begin{array}{c}\text { Mean } \\
\text { Score }\end{array}$ & \multicolumn{1}{|c|}{ Level } \\
\hline 1 & Focus on efficiency improvement & 1.48 & Slightly low focus \\
\hline 2 & $\begin{array}{l}\text { Organization is established in the } \\
\text { industry }\end{array}$ & 3.00 & Relatively established \\
\hline 3 & Employees feel safe in organization & 3.33 & Quite safe \\
\hline 4 & $\begin{array}{l}\text { Employees proud to work in } \\
\text { organization }\end{array}$ & 3.38 & Quite proud of work \\
\hline & Efficiency/Pride Emphasis & 2.80 & Moderately emphasized \\
\hline
\end{tabular}

In contrast, the employees did feel proud to work in the organization and they also feel that they have job security, as shown in the score of 3.33. The respondents also felt that generally, their organizations were quite established in the industry. On the whole, it appeared that there was a sense of pride working for the organizations.

\subsection{Overall Organizational Culture Variable}

The overall inclination of the organization culture was toward a more open and support for the organization, and closeness between management and employees. The organizations generally did support activities that bring management and employees closer. This was supported by the relatively high level of trust that employees had towards management and that the organization did encourage closeness among employees. Evidence also indicated support for 
creativity and risk-taking activities in the organizations, and there was a sense of pride for the employees to work for the organizations as indicated in Table 11.

Table 11 Organization Culture Orientation

\begin{tabular}{|c|l|c|l|}
\hline No & \multicolumn{1}{|c|}{ Factors } & $\begin{array}{c}\text { Mean } \\
\text { Score }\end{array}$ & \multicolumn{1}{|c|}{ Level } \\
\hline 1 & Employee Relationships & 3.57 & $\begin{array}{l}\text { Very close/tight } \\
\text { relationship }\end{array}$ \\
\hline 2 & Creativity/Risk Taking & 2.80 & $\begin{array}{l}\text { Moderate level of } \\
\text { creativity/risk-taking }\end{array}$ \\
\hline 3 & Efficiency/Pride Emphasis & 2.80 & Moderately emphasized \\
\hline & Organizational Culture & 3.06 & Relatively Open \\
\hline
\end{tabular}

The extent of Association between HRM Practices and Organizational Culture

The overall HRM Practices orientation was 2.35 and the organization culture orientation was 3.06. Thus, the difference between the two mean scores was 0.71 or $30 \%$. It was determined that if the percentage difference was $5 \%$ or below, there would be a full relationship, if the difference was over $5 \%$ but under $11 \%$, then there would be a Partial Relationship, and if the difference is over $11 \%$, then there would be no relationship. Therefore, it could be concluded that there was No Relationship between HRM Practices and Organizational Culture as shown in Table 12.

Table 12: Extent of Association between HRM Practices and Organizational Culture

\begin{tabular}{|l|c|c|}
\hline \multicolumn{1}{|c|}{ Variables } & Variance & Extent of Association \\
\cline { 1 - 1 } $\begin{array}{l}\text { HRM Practices Orientation } \\
2.35\end{array}$ & 0.71 & $\begin{array}{c}\text { No } \\
\text { Relationship }\end{array}$ \\
$\begin{array}{l}\text { Organizational Culture } \\
\begin{array}{l}\text { Orientation } \\
3.06\end{array}\end{array}$ & $(30 \%)$ & \\
\hline
\end{tabular}

\section{SUMMARY AND CONCLUSION}

The purposes of the study were to understand the nature of HRM practices in the midscale and upscale hotel organizations, to study the concept of organizational culture in the midscale and upscale hotel organizations, and to determine the extent of association between the HRM practices and the organizational culture orientation. It is proposed that there would be a close association between the HRM practices and the organizational culture orientation.

The overall HRM practices were found to be mixed with some inclination towards meeting current requirements whilst some were more geared towards future requirements. The organization culture orientation was relatively open and in support of employeemanagement relationships, some organizational support for employees' creativity and risktaking activities, and employees' pride with their organizations.

The study had contributed to a better understanding of the HRM practices and cultural orientation in the midscale and upscale hotel organizations. However, further empirical studies needed to be conducted to strengthen the findings from this initial case study on 21 hotel organizations. Regardless, this study has provided insights into some human resources related practices in the hotel organizations. 


\section{REFERENCES}

[1] Afthanorhan, A., Foziah, H., Rusli, R., \& Khalid, S. (2019). Modeling reflective constructs in generalized structure component analysis: An application to service quality and customer satisfaction in UniSZA library. International Journal of Innovation, Creativity and Change, 7(10), 33-41.

[2] Afthanorhan, A., Foziah, H., Rusli, R., \& Khalid, S. (2019). The effect of service quality on customer satisfaction in three campuses of UniSZA. International Journal of Innovation, Creativity and Change, 7(10), 42-56.

[3] Andersen, K.K., Cooper, B.K., \& Zhu, C.J. (2007). The effect of SHRM practices on perceived financial performance: some initial evidence from Australia. Asia Pacific Journal of Human Resources, 45 (2), 168-179.

[4] Armstrong, M. (2001). A handbook of human resource management practice. 8th Edition, London: Kogan Page.

[5] Bach, S. (2005). Managing human resources: Personnel management in transition. Blakenell Publishing.

[6] Chatman, J.A., \& Jehn, K.A. (1994). Assessing the relationship between industry characteristics and organizational culture: How different can you be? Academy of Management Journal, 37, 522-553.

[7] David, F. (2007). Strategic management: Concepts and cases. 13th Edition. Florence, South Carolina: Francis Marion University.

[8] Deshpande, R., \& Webster, F.E. (1989). Organizational culture and marketing: Defining the research agenda. Journal of Marketing, 53, 3-15.

[9] Dowling, P. \& Schuler, R. (1990). International dimensions of human resource management. Boston: PWS-KENT Publishing Company.

[10] Fein, B. (2001). Compensation management strategies. Journal of Personnel Administration, $18 ; 13-27$.

[11] Fombrun, C.J. (2006). Corporate culture, environment, and strategy. Human Resource Management, 22 (1), 139-152.

[12] Fombrun, C.J., Tichy, N.M., \& Devanna, M.A. (1984). Strategic human resource management. New York: Wiley.

[13] Golden, K.A. \& Ramanujam, V. (1985). Between a dream and a nightmare: On the integration of human resource management and strategic business planning. Human Resource Management, 24 (4), 429-452.

[14] Grund, C., \& Przemeck, J. (2012). Subjective performance appraisal and inequality aversion. Applied Economics, 44 (2), 2149-2155.

[15] Hackett, P. (1991). Personnel: The department at work. London: IPM.

[16] Hendry, C. \& Pettigrew, A. (1986). The practice of strategic human resource management. Personnel Review, 15 (5), 3-8.

[17] Holton, E.F., \& Baldwin, T.T. (2000). Making transfer happen: An action perspective on learning transfer systems. Advances in Developing Human Resources, 8, 1-6.

[18] Legge, K. (1995). HRM: Rhetoric, reality and hidden agendas. In Storey, J. (Eds), Human resource management: A critical text. Routledge, London.

[19] Mohamad, M., Nasir, M. N. M., Ab Ghani, N. I., \& Afthanorhan, A. (2019). Parallel mediators of place attachment and tourist satisfaction in destination attractiveness, destination 
Syed Munir Barakbah Syed Faozi Barakbah, Azrin Abdul Razak, May May Grace Derioh and Fakhrulzaman Abdullah

loyalty and service quality. International Journal of Innovation, Creativity and Change, 7(7), 228-256.

[20] O'Reilly, C.A., Chatman, J., \& Caldwell, D.F. (1991). People and organizational culture: A profile comparison approach to assessing person-organization fit. Academy of Management Journal, 34 (3), 487-516.

[21] Olsen, M.D., Tse, E.C., \& West, J.J. (1998). Strategic management in the hospitality industry. 2nd Edition, New York: John Wiley and Sons, Inc.

[22] Paauwe, J., Guest, D.E., \& Wright, P. (2013). HRM and performance: Achievements and challenges. UK: Wiley Press.

[23] Pfeffer, J. (1998). The human equation: Building profits by putting people first. Boston: Harvard Business Press.

[24] Pool, S., \& Pool, B. (2007). A management development model. Journal of Management Development, 26, 353-369.

[25] Rahlin, N. A., Awang, Z., Afthanorhan, A., \& Aimran, N. (2019). The art of covariance based analysis in behaviour-based safety performance study using confirmatory factor analysis: Evidence from SMES. International Journal of Innovation, Creativity and Change, 7(10), 351-370.

[26] Rousseau, D.M. (1990). Assessing organizational culture: The case for multiple methods. In B. Schneider (Ed.), Organizational climate and culture. San Francisco: Jossey-Bass.

[27] Rynes, S.L., Brown, K.G., \& Colbert, A.E. (2002). Seven misconceptions about human resource practices: Research findings versus practitioner beliefs. Academy of Management Executive, 16, 92-103.

[28] SHRM. (2015). Practicing Strategic Human Resources. Society for Human Resource Management, www.shrm.org, October 12.

[29] Storey, J. (1987). Developments in the management of human resources: An interim report. Warwick Papers on Industrial Relations, No. 17, University of Warwick.

[30] Storey, J. (1998). Introduction from personnel management to human resource management. Chapter 1 in Storey, John (ed.), New perspectives on human resource management. London: Routledge.

[31] Walker, J. (1994). Integrating the human resources function with the businesses. Human Resource Journal, 17 (2), 59-77. 